\title{
Magnesium Oxide
}

National Cancer Institute

\section{Source}

National Cancer Institute. Magnesium Oxide. NCI Thesaurus. Code C29242.

The oxide salt of magnesium with antacid, laxative and vascular smooth muscle relaxant activities. Magnesium combines with water to form magnesium hydroxide which reacts chemically to neutralize or buffer existing quantities of stomach acid; stomach-content and intra-esophageal pH rise, resulting in a decrease in pepsin activity. This agent's laxative effect is the result, in part, of osmotically mediated water retention, which subsequently stimulates peristalsis. In addition, magnesium ions may behave as calcium antagonists in vascular smooth muscle. 